jaką kroczyli założyciele pierwszego prywatnego gimnazjum polskiego, które po wielu pertraktacjach z władzami niemieckimi zostało otwarte w. 1937 roku w Kwidzynie.

Stefania Walasek zaprezentowała prywatne szkolnictwo na ziemiach Nowogródzkiego i Wileńskiego KOS w II RP, podkreślając kształt organizacyjny i programowy tamtejszych gimnazjów, który wyłaniał się na tle ówczesnej sytuacji politycznej (tereny te zostały włączone do II RP dopiero w 1922 roku).

Zagadnienie dotyczące szkół prywatnych we wspomnieniach i pamiętnikach zaprezentował Marian Walczak, odtwarzając własne przeżycia, wspomnienia ucznia średniej szkoły prywatnej w latach 1936 - 1939.

W ramach piątego zagadnienia ciekawe badania funkcji społecznej i pedagogicznej internatów szkolnych w II RP zaprezentował Zbigniew Węgierski. Według ustaleń referenta już w 1920 roku działało 12 burs Towarzystwa Szkół Lud., a z czasem liczba ich znacznie wzrastała. Internaty prowadziły: państwo, towarzystwa oświatowe, osoby prywatne. Internaty odgrywały duża rolę wychowawcza - zwracano uwage na wychowanie społeczne, estetyczne, fizyczne, wychowywano zgodnie z oczekiwaniami państwa.

Krzysztof Jakubiak ukazał wiejskie osiedla szkolne prywatnych gimnazjów w II RP, podkreślając znaczną rolę, jaką odegrały $w$ uspołecznianiu młodzieży. Wskazał na wybitnego pedagoga B. Nawroczyńskiego, który rozpoczał propagowanie wiejskich osiedli szkolnych, dzięki czemu w 1933 roku przy Ministerstwie Wyznań Religijnych i Oświecenia Publicznego powstał Zespół Szkół z Wiejskimi Osiedlami Szkolnymi.

Akcentem kończącym sympozjum były głosy dotyczące problemu współczesnego szkolnictwa niepublicznego. Tutaj Jerzy Niemiec prezentując w swoim wystapieniu pluralizm edukacyjny, ujał go w swoisty dekalog tendencji edukacyjnych, poruszając między innymi takie zagadnienia, jak demokratyzacja szkół, pluralizm edukacji, wielokulturowość, która spaja, a nie dzieli społeczeństwo, podmiotowość, europejskość kształcenia.

Wszyscy uczestnicy konferencji w podsumowaniu wyrazili nadzieję na lepszą przyszłość dla szkolnictwa prywatnego, m.in. poprzez sięganie do tradycji edukacyjnych okresu II Rzeczypospolitej.

Prof. Andrzej Gąsiorowski podziękował organizatorom za miłe przyjęcie oraz wspaniała ucztę duchowa.

Organizatorzy dziękując wszystkim za uczestnictwo, zapowiedzieli również druk referatów.

Justyna Gulczyńska

\title{
Konferencja naukowa „Stan i potrzeby badań nad rozwojem oświaty, wychowania i kultury fizycznej w okresie PRL". 8 -9 września 2003 r.
}

Katedra Nauk Humanistycznych Akademii Wychowania Fizycznego i Sportu w Gdańsku, Instytut Pedagogiki Uniwersytetu Gdańskiego - Zakład Historii Nauki i Wychowania oraz Zakład Historii Myśli i Doktryn Pedagogicznych Akademii Bydgoskiej, pod patronatem Towarzystwa Historii Edukacji, w dniach 8 - 9 września 2003 roku, zorganizowali konferencję naukowa nt.: „Stan i potrzeby badań nad rozwojem oświaty, wychowania i kultury fizycznej w okresie PRL".

Problematyka poruszana podczas konferencji spotkała się z bardzo dużym zainteresowaniem, czego dowodem była bardzo duża liczba badaczy z wielu ośrodków naukowych w kraju. Obecni na konferencji przedstawiciele kilku uniwersytetów i innych uczelni przygotowali i wygłosili w czasie obrad plenarnych i obrad trzech grup sekcyjnych przeszło 30 referatów.

Otwarcia konferencji dokonał JM Rektor Akademii Wychowania Fizycznego i Sportu w Gdańsku, prof. dr hab. Wojciech Przybylski. Następnie głos zabrali prof. dr hab. Romuald Grzybowski (Akademia 
Wych. Fizycznego i Sportu w Gdańsku) oraz prof. dr hab. Irena Szybiak, przewodnicząca Towarzystwa Historii Edukacji.

Po uroczystym otwarciu konferencji prof. dr hab. Romuald Grzybowski zaproponował wybór prezydium pod nadzorem którego uczestnicy mieli wygłaszać swoje referaty. Jednomyślnie na członków prezydium zostali wytypowani: prof. dr hab. Irena Szybiak, prof. dr hab. Stanisław Gawlik (Uniwersytet Opolski) i prof. dr hab. Stanisław Mauersberg (IHNOiT PAN).

Po oficjalnym wyborze prezydium Irena Szybiak zaproponowała, aby podczas obrad plenarnych skrócić długość wygłaszanych referatów do 20 minut, z uwagi na znaczna liczbę prelegentów oraz konieczność prowadzenia dalszych obrad w sekcjach.

Jako pierwszy głos zabrał prof. dr hab. Stanisław Gawlik wygłaszając referat pt.: „Budowa podstaw nowego ładu szkolnego (1944-48)". Autor podjał próbę przedstawienia modelowania sytemu szkolnego $\mathrm{w}$ ramach zgodności z Manifestem PKWN. Dowodzil, iż pomimo deklarowania idei Manifestu PKWN odbudowa systemu szkolnego przebiegała zgodnie z ustawa z 1932 roku. Autor przedstawił następnie założenia reformy szkolnictwa w myśl idei komunistycznej, czego głównym wyrazem miało być wprowadzenie w pełni bezpłatnego szkolnictwa (8-letnia szkoła podstawowa z gimnazjum oraz 3-letnie liceum). Ponadto referent przedstawił założenia walki $z$ analfabetyzmem, koleje wprowadzania nowych przedmiotów: języków obcych - głównie języka rosyjskiego, a także języka angielskiego i francuskiego (przedstawił podstawy niechęci do języka niemieckiego); przedmiotu pt.: „Nauka o Polsce oraz Świecie Współczesnym”. Wskazał na czynniki, jakie sprzyjały wprowadzeniu religii do szkół powszechnych, a szczególnie zachęcanie młodzieży przez władze komunistyczne do udziału w nabożeństwach. Autor zaprezentował także zarys tworzenia Centralnej Komisji Kształcenia Nauczycieli w 1946 roku. Prof. Gawlik szczegółowo omówił także „Dekret o utworzeniu wstępnego roku szkolnego na uczelniach państwowych".

Po referacie prof. Gawlika nastąpiła zmiana w porządku obrad i jako kolejny swój referat, pt.: „Nauczyciel wobec indoktrynacji komunistycznej 1947-1956" wygłosił prof. dr hab. Stanisław Mauersberg. W swoim referacie przedstawił on przede wszystkim wpajanie i wymuszanie afirmacji ideologii uznanej za jedynie słuszna przez władze komunistyczne, wymuszanie głoszenia określonych pogladów i prezentowania określonych postaw przez nauczycieli. Autor skupił się zwłaszcza na indoktrynacji środowisk nauczycielskich wg założeń Ministerstwa Oświaty (przymusowe kształcenie ideologiczne wg programu marksistowsko-leninowskiego). Autor omówił także system oceny przydatności nauczyciela do zawodu, gdzie brano pod uwagę głównie kryteria ideologiczne, a nie pedagogiczne oraz sposoby inwigilacji rodzin uczniów przez szczególnie „gorliwych ideologicznie" nauczycieli. Ponadto prelegent omówił sposób, w jaki wpajano „moralność socjalistyczna" rodzicom uczniów chociażby poprzez tworzenie tzw. kół rodziców i trójek klasowych.

W swoim wystapieniu „Oświata w Polsce 1944-1956" prof. dr hab. Andrzej Meissner (Uniwersytet Rzeszowski) poruszył problem, jaki dla władz komunistycznych stanowiła działalność podziemnych działaczy oświatowych, których korzenie sięgały okresu międzywojennego. Autor referatu szczególnie skupił się na sposobie, w jaki władze komunistyczne odnosiły się i traktowały działaczy podziemnych władz oświatowych - próby włączenia w komunistyczną działalność oświatowa lub wysuwanie oskarżeń o szpiegostwo i eliminowanie jednostek niewygodnych.

Prof. dr hab. Krzysztof Jakubiak (Akademia Bydgoska) w referacie nt.: „Relacje rodzina - szkoła w Polsce 1945-1956" poruszył problem zainteresowania władz komunistycznych złożonym problemem badań nad rozwojem rodziny i jej funkcjonowania w społeczeństwie. Szczegółowo omówił socjalistyczną definicję rodziny, gdzie w myśl założeń radzieckich zarówno ojciec, jak i matka byli odpowiedzialni za kształcenie dzieci i ich wychowanie. Dokonał porównania idei rodziny komunistycznej w Polsce do radzieckiego modelu rodziny wg Makarenki, a wiec modelu, w którym ,rodzina to naturalny kolektyw". Autor przedstawił założenia idei komunistycznej, gdzie udział rodziców w wychowaniu dzieci miał się głównie sprowadzać do dotowania finansowego, a nie roli wychowawczej na podstawie wytycznych przedstawicieli Ministerstwa Oświaty, m.in. Włodzimierza Gałeckiego 
z 1948 roku („Poradnik o organizacji pracy w szkole”). Referent omówił także ministerialny projekt tzw. „Samoistnego rodzicielstwa”.

Prof. dr hab. Elwira Kryńska (Uniwersytet w Białymstoku) przedstawiła referat pt.: „Organizacje młodzieży szkół średnich w latach 1945-1956". Autorka zaprezentowała sposób indoktrynacji młodzieży szkolnej przez władze komunistyczne. Autorka przedstawiła w referacie okoliczności rozpadu ZMP, narodziny Związku Młodzieży Socjalistycznej i Związku Młodzieży Wiejskiej oraz zawiązywanie się kólek konspiracyjnych, ich działalność, etapy likwidacji przez władze komunistyczne i sposoby szykanowania ich zdekonspirowanych członków. Autorka omówiła także działalność obozu w Jaworznie oraz stosowane w nim metody „resocjalizacji”. Na uwagę zasługuje również fakt szczegółowego przedstawienia wydarzeń z maja 1955 roku, które doprowadziły do reorganizacji, a ostatecznie zamknięcia obozu.

W swoim referacie pt.: „Dorobek II Rzeczypospolitej w wypracowaniu systemu uniwersyteckiego kształcenia nauczycieli" dr Janina Chodakowska (WSH w Pułtusku) nawiązywała do reform przeprowadzonych w latach 1919 - 1925 przez Ministerstwo Wyznań Religijnych i Oświecenia Publicznego w kwestii programów studiów wyższych. Zwróciła szczególnie uwagę na treść kształcenia, zalożenia ministerialne i uniwersyteckie kształcenia studentów, autonomię wykładu oraz samodzielne rozwiazywanie problemów praktycznych i teoretycznych przez studentów.

Dr Roman Leppert (Akademia Bydgoska) przedstawił referat pt.: „Trzy dyskursy: postęp $\rightarrow$ kryzys - trauma. O możliwości wykorzystania socjologicznego pojmowania zmian społecznych do analizy dziejów pedagogiki w PRL". Prelegent w swoim referacie skupił się głównie na przedstawieniu i omówieniu definicji podstawowych pojęć - postęp, kryzys i trauma. Podjał także kwestie narracji historycznej oraz zmian spolecznych, jakie zaszły w okresie rozwoju pedagogiki PRL.

Przed wystapieniem dr Joanny Wojdon (Uniwersytet Wrocławski) głos zabrał dr Stanisław Majewski (Akademia Świętokrzyska) nawiązując do wystąpienia dr Janiny Chodakowskiej, a zwłaszcza do programów i treści kształcenia zarówno studentów uczelni wyższych, jak również uczniów szkół gimnazjalnych i ponadgimnazjalnych. Swoje uwagi do wystapień referentów - prof. dr hab. Elwiry Kryńskiej i dr Romana Lepperta - dołaczył także prof. dr hab. Romuald Grzybowski.

Po dyskusji głos zabrała dr Joanna Wojdon przedstawiajacc referat nt.: „Partyjna kontrola nad podręcznikami szkolnymi w Polsce Ludowej”. Prelegentka wskazała na sposoby wykorzystywania podręczników z okresu międzywojennego przez Ministerstwo Oświaty z wykorzystaniem cenzury PPR i PZRP. Wskazała również na poszczególne etapy dostosowania tekstów podręczników do ideologii socjalistycznej. Szczególnie dokładnie autorka omówila pierwszy okres istnienia Polski Ludowej z uwzględnieniem lat 1944 - 1946. Wyglaszając referat posługiwała się materiałami archiwalnymi przedstawiajac je słuchaczom za pomoca specjalnie przygotowanych folii i rzutnika.

Po uroczystym obiedzie w tym samym dniu obrad, $z$ uwagi na rozległa tematykę konferencji, zaproponowano prowadzenie dalszych obrad w trzech grupach sekcyjnych.

Sekcja pierwsza pod przewodnictwem prof. dr hab. Sławomira Sztobryna (Chrześcijańska Akademia Teologiczna) podję̧ła dyskusję m.in. na temat przemian organizacyjno-programowych szkolnictwa średniego PRL, źródeł do wych. artystycznego po 1945 roku w Polsce, oświaty PRL po 1973 roku.

Jako pierwsza w dyskusji wystapila dr Teresa Gumuła (Akademia Świętokrzyska) wygłaszając referat nt.: „Problematyka społeczno-pedagogiczna na łamach Nowej Szkoły w latach 1945-1949”. Autorka przedstawiła zawartość roczników „Nowej Szkoły”, ukazujących się w różnym czasie w Łodzi i Warszawie. Przytoczyła wypowiedzi ministrów dotyczące reformy szkolnej, skupiła się na stanowiskach stronnictw politycznych i organizacji młodzieżowych $z$ zakresu omawianej tematyki. Dużo informacji poświęciła szkolnictwu innych krajów, kształceniu i dokształcaniu nauczycieli oraz polityce oświatowej.

Dr Ferdynand Mielczarek (Uniwersytet Opolski) przedstawił referat nt.: „Ideał pedeutologiczny nauczyciela w Polsce Ludowej w latach 1945 - 1956". Autor omówił założenia, w myśl których władze komunistyczne chciały kształtować nowy model nauczyciela, wyróżniający się założonymi cechami, 
m.in. dyspozycyjnością, aktywnością i myśleniem wg schematu socjalistycznego, przekonaniami opartymi na ideałach marksistowskich, odpowiednim światopoglądem, który będzie przekazywał swoim uczniom. Prelegent omówił główne założenia „idealnego nauczyciela”, który w szkole miał być przede wszystkim „działaczem społecznym”, wykonawca woli władz o umiejętnościach organizacyjnych, a nie interpersonalnych czy komunikacyjnych.

Mgr Joanna Kowalska-Matelska (UAM Poznań) przedstawiła stan badań nad dziejami ZNP, wygłaszając referat pt.: „ZNP w latach 1945-1989. Stan badań i perspektywy badawcze”. Autorka zaprezentowala proces odbudowy zwiazku w pierwszych latach powojennych, sfery działalności związku, jego aktywność ideologiczna, wpływ na postawę i działalność nauczycieli. Zwróciła uwagę na konieczność weryfikacji dotychczasowych publikacji dotyczących ZNP w latach Polski Ludowej. Autorka sformułowała postulaty badawcze wymagające pilnego opracowania - m.in.:

- udzial działaczy ZNP w przemianach społeczno-politycznych;

- działalność socjalno-bytowa i kulturalno-oświatowa związku;

- próby emancypacji zawodowej ruchu nauczycieli w okresach przełomu politycznego.

Dr Joanna Król (Uniwersytet Szczeciński) wygłosiła referat pt.: „Polityka rekrutacyjna w odniesieniu do szkół licealnych, a generowanie nowej inteligencji polskiej”. W swoim referacie prelegentka skupiła się głównie na zasadach rekrutacji uczniów do szkół średnich (liceów) oraz pierwszeństwie, jakie miały dzieci pochodzenia robotniczo-chłopskiego. Omówila założenia kształtowania nowej inteligencji $\mathrm{z}$ wykształconej $\mathrm{w}$ odpowiednim schemacie ideologicznym młodzieży robotniczo-chłopskiej.

Po wygłoszeniu referatów w dyskusji głos zabrał dr Stanisław Majewski podkreślając, iż najważniejsza $w$ pracy nauczyciela jest zawsze wiemość własnym poglądom, odpomość na indoktrynację zarówno polityczną, jak i każdą inną. Zwrócił uwagę na fakt, jak trudne jest zweryfikowanie stosunku i postaw do określonych wydarzeń z perspektywy czasu, a zwłaszcza wydarzeń historycznych.

Prof. Irena Szybiak poruszyła kwestie obniżenia wartości wykształcenia średniego ogólnoksztalcącego w latach Polski Ludowej, brak zainteresowania kształceniem ogólnym, a głównie zawodowym, które dawało przede wszystkim możliwość szybkiego zarobkowania. Zwróciła uwagę na fakt braku prestiżu społecznego dla posiadaczy wykształcenia średniego.

Dr Andrzej Michalski (Akademia Bydgoska) poruszył kwestię powielania przez historyków dzieł niejednokrotnie fałszywych, które powstały pod wpływem ideologii i nie służyły poznaniu prawdy historycznej. Podkreślał, że dla historyka szczególnie ważna jest także wiedza z innych dziedzin, np. socjologii czy filozofii.

W sekcji drugiej polemizowano m.in. na temat szkolnictwa żydowskiego w pierwszych latach Polski Ludowej; zadań i oceny pracy nauczyciela w okresie Polski Ludowej; szkolnictwa i oświaty mniejszości narodowych oraz grup etnicznych w strukturach PRL; szkolnictwa morskiego na Pomorzu Zachodnim w okresie Polski Ludowej.

W sekcji trzeciej dyskutowano natomiast nt. kształcenia nauczycieli, tworzenia szkół ogólnokształcących oraz domów dziecka w okresie Polski Ludowej.

$\mathrm{W}$ drugim dniu obrad plenarnych swoje referaty zaprezentowali m.in. prof. dr hab. Stefania Walasek (omawiając szkolnictwo oraz system oświatowy na Dolnym Śląsku po drugiej wojnie światowej) oraz prof. dr hab. Eleonora Sapia-Drewniak (przedstawiając politykę oświatową i spoleczna PRL wobec rodzimej ludności Śląska Opolskiego).

Przedstawione przez referentów zagadnienia oraz kwestie poruszane podczas obrad w sekcjach ukazały różnorodność podejmowanej przez nich problematyki. Dyskusja, w której brali udział członkowie konferencji ukazała jak ważne są tego typu spotkania.

Organizatorzy zapowiedzieli druk materiałów pokonferencyjnych.

Robert Jankowiak 